\title{
Indikator Fundamental Ekonomi Pulau Kalimantan: Analisis Tipologi Daerah
}

\author{
Firman \\ Prodi Perbankan Syariah, Fakultas Ekonomi dan Bisnis Islam, IAIN Pontianak, Pontianak, Indonesia \\ Email: firmankuburaya@gmail.com \\ Email Penulis Korespondensi: firmankuburaya@gmail.com \\ Submitted: 17/11/2021; Accepted: 27/11/2021; Published: 30/11/2021
}

\begin{abstract}
Abstrak-Pembangunan ekonomi dearah kepulaun sering terjadi ketimpangan baik dari jumlah penduduk dan jumlah pengangguran yang relative besar, infrastruktur kurang memadai, serta sarana dan prasana pendidikan serta kesehatan yang belum maksimal. Tujuan penelitin ini untuk mengetahui tipologi daerah Pulau Kalimantan dilihat dari indikator fundamental ekonomi daerah dengan menggunakan data sekunder provinsi Kalimantan Barat, Kalimantan Selatan, Kalimantan Utara, Kalimantan Timur dan Kalimantan Tengah dengan menggunakan analisis tipologi daerah dengan waktu penelitian tahun 2015-2020 yang bersumber dari Badan Pusat Statistik. Hasil penelitian ini menemukan bahwa Pulau Kalimantan memiliki ketimpangan yang cukup tinggi, walaupun dari tahun 2015-2020 dari data Gini rasio mengalami peningkatan, selain itu juga dilihat dari tipologi daerah kelima Provinsi di Kalimantan tidak ada satupun yang memiliki pertumbuhan ekonomi, PDRB Perkapita dan IPM/HDI secara bersama-sama memiliki nilai tinggi, artinya bahwa ada daerah dengan pertumbuhan ekonomi dan PDRB tinggi, tetapi IPM/HDI rendah dan sebaliknya. Kalimantan Utara merupakan daerah dengan kategori cepat maju dan cepat tumbuh karena memiliki nilai pertumbuhan ekonomi dan pendapatan perkapita yang tinggi, Kalimantan Timur yang memiliki kualifikasi daerah maju dan cepat tumbuh, yakni dengan pendapatan tinggi diikuti juga oleh IPM/HDI, Kalimantan Tengah dan Kalimantan Utara masuk kategori daerah potensial atau daerah maju tepi tertekan atau daerah dengan pertumbuhan ekonomi tinggi tetapi IPM/HDI rendah.
\end{abstract}

Kata Kunci: Fundamental Ekonomi; Tipologi Daerah; Pulau Kalimantan

\begin{abstract}
The economic development of the island regions often results in inequality both in terms of population and relatively large unemployment, inadequate infrastructure, and inadequate education and health facilities and infrastructure. The purpose of this study was to determine the regional typology of the island of Kalimantan in terms of regional economic fundamental indicators by using secondary data from the provinces of West Kalimantan, South Kalimantan, North Kalimantan, East Kalimantan and Central Kalimantan using regional typology analysis with a research period of 2015-2020 sourced from the National Agency of Drug and Food Control. Center for Statistics. The results of this study found that the island of Kalimantan has a fairly high inequality, although from 2015 2020 the Gini ratio has increased, besides that it is also seen from the typology of the five provinces in Kalimantan that none of them has economic growth, GRDP per capita and HDI/ Together, HDI has a high value, meaning that there are regions with high economic growth and GRDP, but low HDI/HDI and vice versa. North Kalimantan is an area with a fast-developing and fast-growing category because it has a high value of economic growth and per capita income, East Kalimantan which has advanced and fast-growing regional qualifications, namely those with high incomes, followed by HDI, Central Kalimantan and North Kalimantan are included. the category of potential areas or developed regions on the edge of depression or areas with high economic growth but low HDI.
\end{abstract}

Keywords: Economic Fundamentals; Regional Typology; Kalimantan Island

\section{PENDAHULUAN}

Kualitas sumberdaya manusia dengan produktivitas tenaga kerja yang tinggi serta pemerataan pembangunan dan pertumbuhan ekonomi merupakan salah satu tujuan pembangunan ekonomi baik pusata ataupun daerah. Pergeseran makna dari pembangunan, agaknya jelas bahwa dalam penyusunan fundamental ekonomi diperlukan identifikasi sasaran dalam penyususnan indikator fundamental ekonomi daerah, karena penyusunan indikator ekonomi merupakan kebutuhan yang mendesak bagi suatu daerah (Kuncoro, 2015a).

Sasaran fundamental yang ingin dicapai dalam pembangunan suatu daerah meliputi: (1) peningkatan laju pertumbuhan ekonomi daerah, (2) peningkatan pendapatan per kapita, dan (3) pengurangan kemiskinan, pengangguran dan ketimpangan, serta (4) peningkatan kualitas pembangunan manusia. Pulau Kalimantan adalah salah satu pulau yang kaya akan sumberdaya alam seperti hasil hutan, perkebunan, gas, minyak dan batubara. Banyak negara yang terjebak pada ketimpangan yang lebar dan kasus kemiskinan yang cukup parah. Hal ini menunjuk-kan bahwa ketimpangan menjadi isu penting yang tidak dapat dipandang sebelah mata dan dibiarkan.

Pertumbuhan ekonomi merupakan salah satu indikator untuk melihat kinerja perekonomian, baik di tingkat nasional maupun regional (daerah) (Lumbantoruan \& Hidayat, 2014). Menurut Todaro dalam (Suntari \& Yunani, 2019) pertumbuhan ekonomi didefinisikan sebagai suatu proses dimana kapasitas produksi dari suatu perekonomian meningkat sepanjang waktu untuk menghasilkan tingkat pendapatan yang semakin besar. Begitu juga menurut (Wihastuti, 2008) Pertumbuhan ekonomi merupakan salah satu indikator keberhasilan pembangunan di suatu perekonomian. Kesejahteraan dan kemajuan suatu perekonomian ditentukan oleh besarnya pertumbuhan yang ditunjukkan oleh perubahan output nasional. Adanya perubahan output dalam perekonomian merupakan analisis ekonomi jangka pendek. 


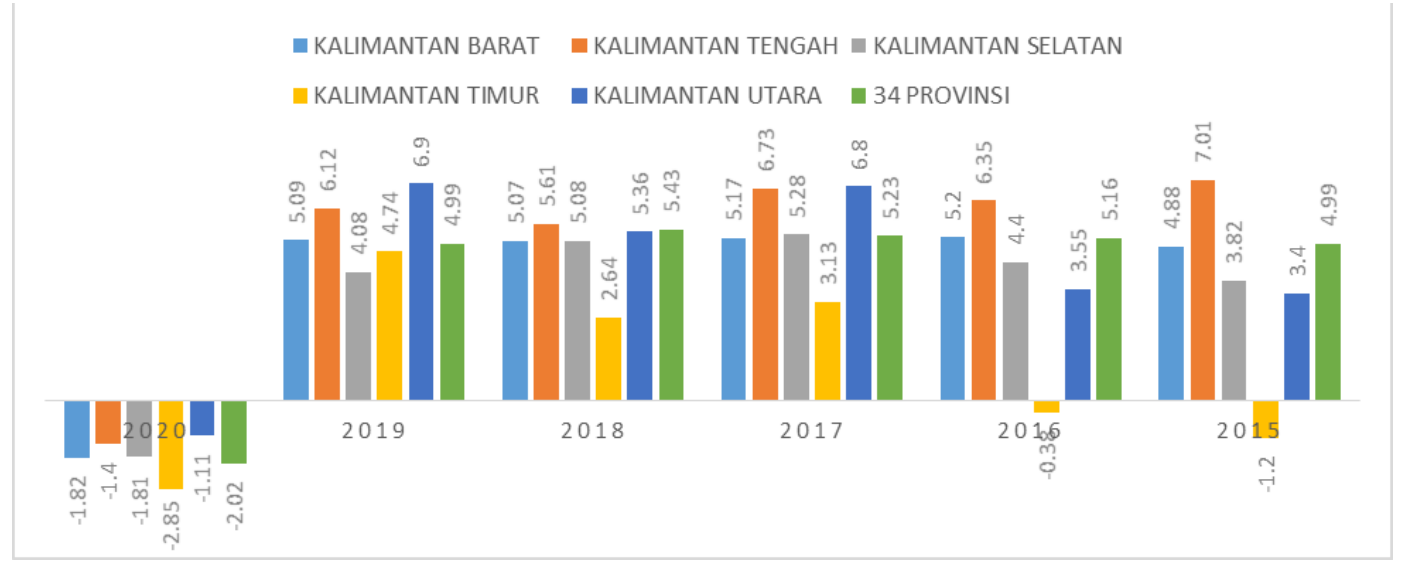

Gambar 1. Pertumbuhan Ekonomi Pulau Kalimantan Tahun 2015-2020

Pada tahun 2015 dan 2016 pertumbuhan ekonomi terendah adalah provinsi Kalimantan Timur, yakni pertumbuhan ekonomi Kalimantan Timur sebesar $-1,2$ dan 0,38\% \%. Kinerja ekonomi Kalimantan Timur Triwulan III-2015 yang diukur berdasarkan perkembangan PDRB pada triwulan III-2015 dibanding triwulan II-2015 terkoreksi sebesar -1,47 persen $(q-t o-q)$. Jika dibandingkan dengan triwulan yang sama tahun 2014 juga terkoreksi, yaitu sebesar $-3,49$ persen $(y$ on-y). Secara kumulatif, pertumbuhan ekonomi Kalimantan Timur dari Triwulan I hingga Triwulan III-2015 dibandingkan dengan periode yang sama tahun 2014 mengalami kontraksi sebesar -1,65 persen $(c$-to-c). Dari sisi produksi, pertumbuhan ekonomi triwulan III-2015 secara $y$-on-y dipengaruhi oleh penurunan kinerja Lapangan Usaha Pertambangan dan Penggalian yang terkoreksi sebesar -9,61 persen dan Industri Pengolahan yang juga terkoreksi sebesar $-1,16$ persen, yang berimbas pada penurunan Jasa Perusahaan sebesar $-4,81$ persen. Dari sisi pengeluaran dipengaruhi oleh komponen Ekspor Luar Negeri yang mengalami koreksi cukup signifikan sebesar -13,56 persen (BPS, 2016).

Meskipun PDRB Kalimantan Timur tinggi, namun sebagian besar dikontribusi oleh sektor dari sumber daya alam yang tak terbarui terutama sektor minyak, gas dan batubara. Hal ini akan menjadi sebuah masalah utama jika sumber daya alam tak terbarui tersebut makin menipis dan pemerintah belum maksimal mendorong pertumbuhan sektor-sektor strategis lain yang menunjang perekonomian (BPS, 2016).

Kalimantan Tengah, Kalimantan Utara dan Kalimantan Barat merupakan daerah dengan pertumbuhan ekonomi tertinggi dari pulau Kalimantan lainnya, dari 5 tahun terakhir pertumbuhan tinggi yakni Kalimantan Tengah, dimana tahun 2015 Kalimantan tengah yakni sebesar 7,01\%. Rendahnya pertumbuhan ekonomi Kalimantan Timur merupakan salah satu sebab fundamental ekonomi daerah tersebut tidak berjalan sempurna, apalagi saat pandemic yang mulai masuk ke Indonesia pada tahun 2020, Kalimantan Timur merupakan dengan pertumbuhan ekonomi dengan minus paling dalam yakni sebesar $-2,85 \%$, melebihi dari minus pertumbuhan ekonomi Indonesia yakni $-2,02 \%$.

Pebedaan pertumbuhan ekonomi antar daerah Pulau Kalimantan akan berdampak terhadap kesenjangan dimasyarakat khususnya masyarakat di Kalimantan. Permasalahan pokok dalam pembangunan ekonomi adalah peningkatan Gross Domestic Product (GDP), pengurangan kesenjangan pendapatan dan penghapusan kemiskinan. Di beberapa negara tujuan tersebut kadang-kadang menjadi sebuah dilema antara mementingkan pertumbuhan ekonomi atau mengurangi kesenjangan pendapatan (Waluyo, 2006).

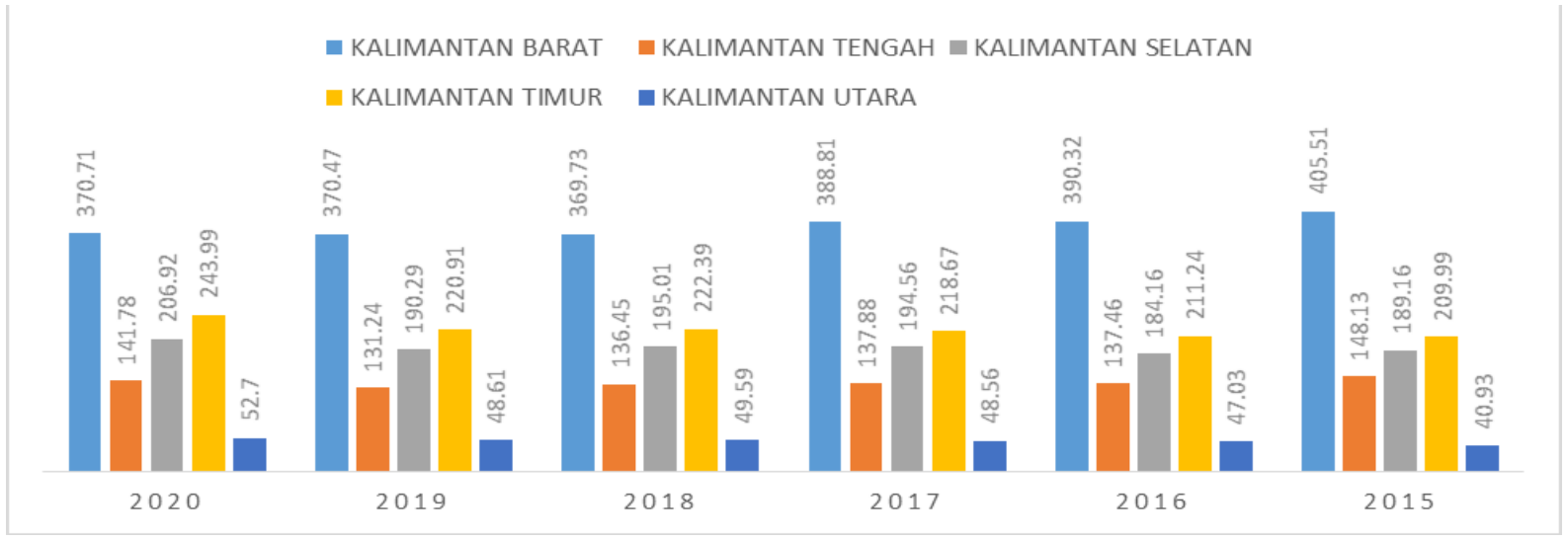

Gambar 2. Jumlah Penduduk Miskin (Rp.) Pulau Kalimantan Tahun 2015-2020

Pembangunan dalam lingkup negara secara spasial tidak selalu merata. Kesenjangan antar daerah seringkali menjadi permasalahan yang serius. Beberapa daerah dapat mencapai pertumbuhan yang signifikan, sementara beberapa daerah lainnya mengalami pertumbuhan yang lambat. Daerah yang tidak mengalami kemajuan yang sama disebabkan karena kurangnya sumber-sumber yang dimiliki; adanya kecendrungan pemilik modal (investor) memilih daerah 
perkotaan atau daerah yang memiliki fasilitas seperti prasarana perhubungan, jaringan listrik, jaringan telekomunikasi, perbankan, asuransi juga tenaga terampil (Ismail, 2020).

Pemerintah daerah memerlukan informasi kemiskinan menurut sektor ekonomi untuk membuat kebijakan investasi yang berbasis kemiskinan, guna mempercepat program pengentasan kemiskinan. Salah satu sebab kemiskinan masih terjadi didaerah pedesaan adalah karena imbas dari alokasi anggaran pemerintah baik pusat dan daerah dalam kurang seimbang, dimana sebagian besar anggaran atau alokasi anggaran lebih bertumpu pada sector industry atau perdagangan sementara sector pertanian yang merupakan terletak di pedesaan setiap tahunnya mengalami penurunan. Para petani di desa cenderung miskin karena cara dan pola pengembangan pertanian yang tradisioanal dan hanya bertani untuk kehidupan sendiri dan keluarga, artinya bahwa masyarakat desa bertani hanya untuk kehidupan sehari-hari mereka.

Selama lima tahun terakhir penduduk miskin terbanyak di pulau Kalimantan adalah Kalimantan Barat, dimana tahun 2020 jumlah penduduk miskin di Kalimantan Barat sudah mencapai 370,71 ribu jiwa walaupun mengalami pengurangan jumlah penduduk miskin dari tahun 2015 yakni sebesar 405,51 ribu jiwa perbedaan jumlah penduduk miskin sangat besar jika dibandingkan dengan jumlah penduduk miskin di provinsi Kalimantan lainnya seperi Kalimantan Utara merupakan provinsi di Kalimantan dengan jumlah penduduk miskin paling sedikit walaupun setiap tahunnya mengalami peningkatan, yakni pada tahun 2015 sebesar 40,93 ribu jiwa menjadi 52,7 ribu jiwa pada tahun 2020 .

Kalimantan salah satu pulau yang kaya dengan sumber daya alam yang melimpah, seperti batu bara, hutan, perkebunan, minyak dan gas merupakan salah satu kekayaan dibumi yang ada di Pulau Kalimantan. Oleh karena itu perlu pengembangan sektor ekonomi menjadi kebijakan yang diperlukan untuk meningkatkan perekonomian dan mengurang jumlah penduduk miskin (Murohman et al., 2018). Adapun tujuan penelitian ini adalah untuk menganalisis indikator fundamental ekonomi di Pulau Kalimantan, yakni pertumbuhan ekonomi, PDRB perkapita, pengangguran, ketimpangan dan IPM tahun 2015-2020. Sehingga dari penelitian ini muncul rumusan dan masukkan kepada pemerintah khususnya pemerintah Provinsi yang ada di Pulau Kalimantan agar lebih tepat membuat sasaran pembangunan daerah sehingga mampu meningkatkan pertumbuhan ekonomi, pendapatan dan IPM yang merata, serta mampu mengurangi ketimpangan dan pengangguran.

\section{METODE PENELITIAN}

Jenis data dalam penelitian ini adalah data kuantitatif dan sumber data yang digunakan adalah data sekunder. Penelitian ini menganalisis Tipologi Daerah berdasarkan indikator Fundamental Ekonomi di Pulau Kalimantan pada tahun 20152020 dengan data yang digunakan adalah pertumbuhan ekonomi, PDRB per kapita, pengangguran, ketimpangan dan IPM/HDI provinsi di 5 pulau Kalimantan, yakni Kalimantan Barat, Kalimantan Tengah, Kalimantan Selatan, Kalimantan Timur dan Kalimantan Utara. Adapun data bersumber data Badan Pusat Statistik Indonesia dan beberapa literatur dan informasi yang tertulis baik dari buku dan jurnal yang berhubungan dengan judul yang peneliti lakukan.

Alat yang digunakan untuk menjawab tujuan penelitian ini adalah, peneliti menggunakan alat tipologi daerah, dimana alat ini digunakan untuk mengetahui gambaran tentang pola dan struktur pertumbuhan ekonomi masing-masing daerah (Kuncoro, 2015a). Dalam mendapatkan hasil, peneliti membuat kreteria yang digunakan untuk membagi provinsi pulau Kalimantan sebagai berikut, yaitu; (1) daerah cepat maju dan cepat tumbuh atau provinsi yang memiliki pertumbuhan ekonomi tinggi dan pendapatan perkapita tinggi; (2) daerah maju tepi tertekan atau daerah dengan pendapatan tinggi tetapi pertumbuha ekonomi rendah; (3) daerah berkembang cepat, yakni dengan pertumbuhan ekonomi tinggi tetapi pendatan perkapita rendah; (4) daerah relative tertinggal, yakni pertumbuhan ekonomi dan pendapatan per kapita rendah. Untuk lebih jelasnya dapat dilihat pada table 1.

Tabel 1. Tipologi Daerah

\begin{tabular}{|c|c|c|}
\hline $\begin{array}{l}\text { PDRB Per Kapita (y) } \\
\text { Pertumbuhan Ekonomi (r) }\end{array}$ & $(\mathbf{y} 1>y)$ & $(y 1<y)$ \\
\hline$(\mathbf{r} 1>\mathbf{r})$ & $\begin{array}{l}\text { Pendapatan tinggi \& } \\
\text { pertumbuhan tinggi }\end{array}$ & $\begin{array}{l}\text { Pendapatan rendah dan pertumbuhan } \\
\text { tinggi }\end{array}$ \\
\hline$(\mathbf{r} 1<\mathbf{r})$ & $\begin{array}{l}\text { Pendapatan tinggi dan } \\
\text { pertumbuhan rendah }\end{array}$ & $\begin{array}{l}\text { Pendapatan rendah dan pertumbuhan } \\
\text { rendah }\end{array}$ \\
\hline
\end{tabular}

Keterangan:

Sumber : (Kuncoro, 2015b)

r : Rata-rata pertumbuhan ekonomi Pulau Kalimantan

y : Rata-rata PDRB per kapita Pulau Kalimantan

ri $\quad$ : Pertumbuhan ekonomi pulau Kalimantan yang diamati (i)

yi $\quad$ : PDRB per kapita pulau Kalimantan yang diamati (i)

Untuk mendapatkan hasil yang kedua yakni peneliti juga membagi kreteria dengan; (1) daerah cepat maju dan cepat tumbuh atau provinsi yang memiliki pendapatan perkapita tinggi dan HDI tinggi; (2) daerah maju tepi tertekan atau daerah dengan HDI tinggi tetapi pendapatan perkapita rendah; (3) daerah berkembang cepat, yakni dengan pendapatan 
perkapita tinggi tetapi HDI rendah; (4) daerah relatif tertinggal, yakni pendapatan perkapita dan HDI rendah. Lebih jelasnya dapat dilihat pada tabel 2 .

Tabel 2. Tipologi Daerah

\begin{tabular}{|c|c|c|}
\hline $\begin{array}{l}\text { PDRB Per Kapita (y) } \\
\text { IPM/ HDI }\end{array}$ & $(y 1>y)$ & $(\mathbf{y} 1<y)$ \\
\hline$(\mathbf{r} 1>\mathbf{r})$ & $\begin{array}{l}\text { Pendapatan tinggi \& IPM/ HDI } \\
\text { tinggi }\end{array}$ & $\begin{array}{l}\text { Pendapatan rendah dan IPM/ HDI } \\
\text { tinggi }\end{array}$ \\
\hline$(\mathbf{r} 1<\mathrm{r})$ & $\begin{array}{l}\text { Pendapatan tinggi dan IPM/ HDI } \\
\text { rendah }\end{array}$ & $\begin{array}{l}\text { Pendapatan rendah dan IPM/ HDI } \\
\text { rendah }\end{array}$ \\
\hline
\end{tabular}

Keterangan:

$\begin{array}{ll}\text { r } & \text { : Rata-rata IPM/ HDI Pulau Kalimantan } \\ \text { y } & \text { : Rata-rata PDRB per kapita Pulau Kalimantan } \\ \text { ri } & \text { : IPM/ HDI pulau Kalimantan yang diamati } \\ \text { yi } & \text { : PDRB per kapita pulau Kalimantan yang }\end{array}$

Untuk mendapatkan hasil yang ketiga, peneliti juga membagi kreteria dengan; (1) daerah cepat maju dan cepat tumbuh atau provinsi yang memiliki pertumbuhan ekonomi tinggi dan HDI tinggi; (2) daerah maju tepi tertekan atau daerah dengan HDI tinggi tetapi pertumbuhan ekonomi rendah; (3) daerah berkembang cepat, yakni dengan pertumbuhan ekonomi tinggi tetapi HDI rendah; (4) daerah relatif tertinggal, yakni pertumbuhan ekonomi dan HDI rendah. Lebih jelasnya dapat dilihat pada table 3 .

Tabel 3. Tipologi Daerah

Pertumbuhan Ekonomi (y)
$(\mathbf{y} 1>\mathbf{y})$
$(\mathbf{y} 1<\mathbf{y})$

IPM/HDI

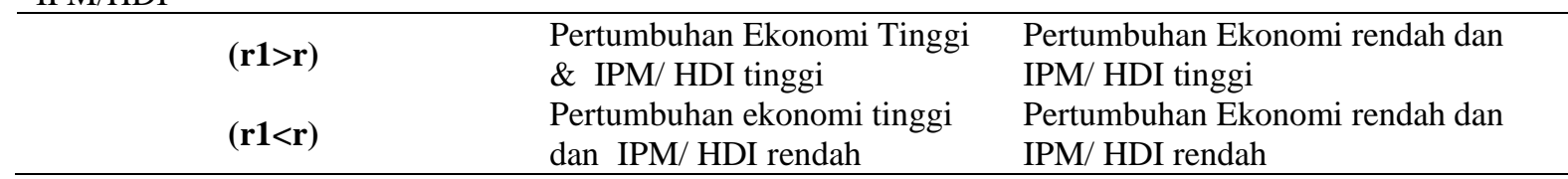

\begin{tabular}{cl}
\hline Keterangan: & \\
r & : Rata-rata IPM/ HDI Pulau Kalimantan \\
y & : Rata-rata Pertumbuhan Ekonomi Pulau Kalimantan \\
ri & : IPM/ HDI pulau Kalimantan yang diamati \\
yi & $:$ Pertumbuhan Ekonomi pulau Kalimantan yang
\end{tabular}

\section{Indeks Williamson (IW)}

Untuk mengetahui ketimpangan pembangunan antar Kalimantan dapat dianalisi dengan menggunakan indeks ketimpangan regional (regional inequality) yang dinamakan indeks ketimpangan Williamson. Indeks ketimpangan regional ini diformulasikan (Kuncoro, 2015a) sebagai berikut:

$$
\mathrm{IW}=\frac{\sqrt{\sum_{\mathrm{i}=0}^{\mathrm{n}\left(\mathrm{Y}_{\mathrm{i}}-\mathrm{Y}\right)^{2}(\mathrm{fi} / \mathrm{n})}}}{\mathrm{Y}} .
$$

Keterangan:

$\mathrm{Yi}=$ PDRB per kapita Kalimantan

$\mathrm{Y}=\mathrm{PDRB}$ rata-rata per kapita Indonesia

fi $=$ jumlah penduduk Kalimantan

$\mathrm{n} \quad=$ jumlah penduduk Indonesia

Untuk mengukur ketimpangan Ekonomi (pendapatan) antar wilayah Indeks Williamson (Iswanto \& Maski, 2013), IW berkisar antara $0-1$

a. Bila IW, $<0,3$ artinya : ketimpangan ekonomi wilayah rendah

b. Bila IW, 0,3 - 0,5 artinya ketimpangan ekonomi wilayah sedang

c. Bila IW.>0,5 artinya ketimpangan ekonomi wilayah tinggi

Indek Entropi Theil (IT)

Selain menggunakan Indeks Williamson, dalam mengukur suatu ketimpangan pendapatan di Indonesia menggunakan Indeks Theil (Kuncoro, 2015b). Adapaun antar pulau digunakan persamaannya adalah:

$$
\mathrm{I}(\mathrm{y})=\sum(y j / Y) x \log [(y j / Y) /(x j / X)]
$$

Di mana: 


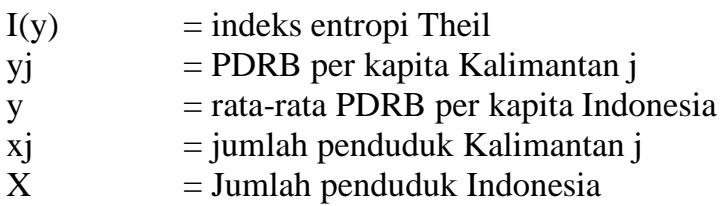

Indeks Entropy Theil yang semakin besar menunjukkan bahwa ketimpangan yang terdapat pada suatu daerah/wilayah semakin besar atau ketimpangan di daerah tersebut tidak merata. Demikian juga, apabila indeks Entropy Theil semakin kecil menunjukkan bahwa ketimpangan yang terdapat di suatu daerah/wilayah tersebut semakin kecil/rendah atau dapat dikatakan ketimpangan pada daerah tersebut semakin merata (Kuncoro, 2015a).

\section{HASIL DAN PEMBAHASAN}

Dalam menjawab dari ketiga tujuan penelitian ini, peneliti membagi hasil tipologi daerah menjadi tiga bagian, yakni PDRB Perkapita dan Pertumbuhan Ekonomi, PDRB Perkapita dan HDI/IPM, serta Pertumbuhan Ekonomi dan HDI/IPM.

\section{PDRB Perkapita dan Pertumbuhan Ekonomi}

Adapun hasil dari penelitian ini peneliti klasifikasi menjadi empat kompenen, yakni 1) Daerah cepat maju dan cepat tumbuh atau provinsi yang memiliki pertumbuhan ekonomi tinggi dan pendapatan perkapita tinggi; 2) daerah maju tepi tertekan atau daerah dengan pendapatan tinggi tetapi pertumbuhan ekonomi rendah; 3) daerah berkembang cepat, yakni dengan pertumbuhan ekonomi tinggi tetapi pendapatan perkapita rendah; 4) daerah relative tertinggal, yakni pertumbuhan ekonomi dan pendapatan per kapita rendah. Adapun hasil dari penelitian ini dapat dilihat pada tabel 4.

Tabel 4. PDRB Perkapita dan Pertumbuhan Ekonomi

\begin{tabular}{|c|c|c|}
\hline \multirow{3}{*}{$\begin{array}{l}\text { Pertumbuhan } \\
\text { Ekonomi (r) }\end{array}$} & \multicolumn{2}{|c|}{ PDRB Per Kapita (y) } \\
\hline & $(\mathrm{y} 1>\mathrm{y})$ & $(\mathrm{y} 1<\mathrm{y})$ \\
\hline & & \\
\hline \multirow[t]{2}{*}{$(\mathrm{r} 1>\mathrm{y})$} & $\begin{array}{l}\text { Pendapatan tinggi \& pertumbuhan tinggi: } \\
\text { Kalimantan Utara }\end{array}$ & $\begin{array}{l}\text { Pendapatan rendah dan pertumbuhan } \\
\text { tingoi. }\end{array}$ \\
\hline & & Kalimantan Tengah \\
\hline \multirow[t]{3}{*}{$(\mathrm{r} 1<\mathrm{y})$} & $\begin{array}{l}\text { Pendapatan tinggi dan pertumbuhan } \\
\text { rendah: }\end{array}$ & $\begin{array}{l}\text { Pendapatan rendah dan pertumbuhan } \\
\text { rendah: }\end{array}$ \\
\hline & Kalimantan Timur & Kalimantan Barat \\
\hline & & Kalimantan Selatan \\
\hline
\end{tabular}

Pembagian ini yakni PDRB per kapita dan pertumbuhan ekonomi, pada kuadran pertama, yakni daerah cepat maju dan cepat tumbuh atau pendapatan tinggi dan pertumbuhan tinggi hanya ada satu provinsi yakni Provinsi Kalimantan Utara dimana rata-rata PDRB perkapita Kalimantan Utara dari tahun 2015-2020 sebesar Rp.79.062.59 ribu rupiah dan dengan pertumbuhan ekonomi sebesar $4.15 \%$.

Daerah dengan kategori daerah maju tepi tertekan atau daerah dengan pendapatan tinggi tetapi pertumbuhan ekonomi rendah tidak ada. Sedangkan untuk daerah dengan kategori daerah berkembang cepat, yakni dengan pertumbuhan ekonomi tinggi tetapi pendapatan perkapita rendah hanya satu yakni Kalimantan Tengah, dan untuk kategori daerah relative tertinggal, yakni pertumbuhan ekonomi dan pendapatan per kapita rendah adalah sebagian besar provinsi Kalimantan berada diposisi daerah relatih tertinggal, yakni Kalimantan Barat, dan Kalimantan Selatan.

Kalimantan Utara merupakan Provinsi di Kalimantan yang dibilang daerah cepat maju dan cepat tumbuh, dimana penyumbang terbesar terhadap PDRB ADHK Kalimantan Utara adalah sector Pertambangan dan Penggalian yakni sebesar 25,45\% pada tahun 2020, atau sebesar Rp. 15.664.218,8 juta rupiah dan terbesar di subsector Pertambangan Batubara dan Lignit yakni Rp.9.882 .804,7 juta rupiah. Penyebab utama Kalimantan Utara masuk daerah derah maju dan cepat berkembang adalah jumlah penduduk yang sangat sedikit dibandingkan dengan daerah Kalimantan lainnya, dimana pada tahun 2020 persentase penduduk Kaltara adalah hanya 4\% dari jumlah penduduk di Pulau Kalimantan atau penduduk Kaltara sebanyak 708.4 ribu jiwa dari jumlah penduduk Pulau Kalimantan yakni 16.432.9 ribu jiwa dan penduduk tebesar adalah Kalimantan Barat 32\%, Kalimantan Selatan 25\% dan Kalimantan Timur 23\%.

Sedangkan darah dengan pendapatan rendah dan pertumbuhan rendah seperti Kalimantan Barat penyumbang terbesar terahadap PDRB adalah sector pertanian, Kehutanan dan perikanan, dimana pada tahun 2020 sebesar Rp. 32.340.499,90 atau 24\% dan industry pengolahan yakni sebesar 15\%, sedangkan untuk Kalimantan Selatan penyumbang terbesar PDRB adalah sector Pertambangan dan Penggalian yakni sebesar 24,39\% atau sebesar Rp. 31.920.344,87 juta rupiah, sedangkan untuk Kalimantan Timur dimana distribusinya tertinggi terhadap PDRB pada tahun 2020 adalah Pertambangan dan Penggalian yakni sebesar 41,43\% atau sebesar Rp.223.064.386,07 juta rupiah dan disusul oleh Indsutri pengolahan yakni sebesar 18,90\% atau sebesar Rp.94.146.617,30 juta rupiah.

Pertumbuhan ekonomi daerah merupakan hal penting dalam pembangunan daerah dan pertumbuhan ekonomi daerah tidak akan terwujud bila tidak ada pertumbuhan produksi dan jasa (Sjafrizal, 2018). Perkembangan jumlah penduduk bisa menjadi faktor pendorong dan penghambat pembangunan. Faktor pendorong, karena dapat memungkinkan 
semakin banyak tenaga kerja yang tersedia dan perluasan pasar. Luas pasar barang dan jasa ditentukan oleh dua faktor penting, yaitu pendapatan masyarakat dan jumlah penduduk. Penduduk disebut faktor penghambat pembangunan karena akan menurunkan produktivitas dan akan banyak pengangguran (Sukirno, 2016). Selain itu juga perbedaan dari kesenjangan antar provinsi atau daerah perkotaan dan pedesaan dalam hal kemiskinan tentu berkaitan dengan pembangunan ekonomi, termasuk kondisi pasar tenaga kerja, jumlah penduduk, struktur pendidikan formal (Tambunan, 2016).

\section{PDRB Perkapita dan IPM/HDI}

Begitu juga PDRB perkapita dan IPM/HDI peneliti mengklasifikasi menjadi empat kompenen, yakni 1) Daerah cepat maju dan cepat tumbuh atau provinsi yang memiliki IPM/HDI tinggi dan pendapatan perkapita tinggi; (2) daerah maju tepi tertekan atau daerah dengan pendapatan tinggi tetapi IPM/HDI rendah; (3) daerah berkembang cepat, yakni dengan IPM/HDI tinggi tetapi pendapatan perkapita rendah; (4) daerah relative tertinggal, yakni IPM/HDI dan pendapatan per kapita rendah. Adapun hasil dari penelitian ini dapat dilihat pada tabel 5.

Tabel 5. PDRB Perkapita dan IPM/HDI

\begin{tabular}{|c|c|c|}
\hline \multirow[b]{2}{*}{ IPM/HDI (r) } & \multicolumn{2}{|c|}{ PDRB Per Kapita (y) } \\
\hline & $(y 1>y)$ & $(\mathrm{y} 1<\mathrm{y})$ \\
\hline$(\mathrm{r} 1>y)$ & $\begin{array}{l}\text { Pendapatan tinggi \& IPM/HDI tinggi: } \\
\text { Kalimantan Timur }\end{array}$ & Pendapatan rendah dan IPM/HDI tinggi: \\
\hline$(\mathrm{r} 1<\mathrm{y})$ & $\begin{array}{l}\text { Pendapatan tinggi dan IPM/HDI } \\
\text { rendah: } \\
\text { Kalimantan Utara }\end{array}$ & $\begin{array}{l}\text { Pendapatan rendah dan IPM/HDI rendah: } \\
\text { Kalimantan Barat } \\
\text { Kalimantan Tengah } \\
\text { Kalimantan Selatan }\end{array}$ \\
\hline
\end{tabular}

Dari tabel di atas menjelaskan tentang PDRB perkapita dan IPM/HDI Provinsi Kalimantan, dimana pada tabel di atas menjelaskan bahwa hanya satu Provinsi yang berada pada klasifikasi Daerah cepat maju dan cepat tumbuh atau provinsi yang memiliki IPM/HDI tinggi dan pendapatan perkapita tinggi, yakni Kalimantan Timur, dimana pada tahun 2015-2020 PDRB perkapita Kalimantan Timur sebesar Rp.127,236.43 juta rupiah dengana IPM/HDI 75.43.

Sedangkan Kalimantan lainnya yakni, Kalimantan Utara ada pada posisi daerah maju tepi tertekan atau daerah dengan pendapatan tinggi tetapi IPM/HDI rendah dan untuk provinsi Kalimantan Barat Kalimantan Tengah dan Kalimantan Selatan berada pada posisi daerah relative tertinggal, yakni dengan IPM/HDI dan pendapatan per kapita rendah.

Kalimantan Timur (Kaltim) merupakan daerah dengan IPM tertinggi diantara pulau Kalimantan lainnya, dimana pada tahun 2020 IPM Kaltim adalah sebesar 76,24 dan terendah adalah Kalimantan Barat yakni sebesar 67,66, dimana Rata-Rata Lama Sekolah sebesar 9,77 tahun, dengan harapan lama sekolah 13,72 tahun, sedangkan untuk Umur Harapan Hidup (UHH) adalah sebesar 74,33 tahun dan pengeluaran per kapita sebesar Rp. 11.728,00 ribu rupiah.

Menurut Amartha Sen dalam (Putra, 2018) menerangkan bahwa kelaparan terjadi bukan karena kekurangan bahan makanan tetapi karena tidak meratanya pembangunan pemerataan distribusi makanan. Kalimantan Utara walaupun IPM rendah tetapi pendapatn perkapita daerah tersebut tinggi, dimana IPM Kaltara sebesar 70,63 tahun 2020, sedangkan provinsi Kalbar, Kalteng, dan Kalsel merupaha daerah dengan pendapatan rendah dan HDI rendah, IPM Kalbar merupakan IPM terendah dari tahun 2015-2020, dimana tahun 2020 IPM Kalbar sebesar 67,66 dengan rata-rata lama Sekolah 7,3 tahun, Harapan Lama Sekolah sebesar 12,60, Angka Harapan Hidup (AHH) sebesar 70,69 tahun dan Pengeluaran Perkapita Pertahun adalah sebesar Rp. 8.930,00, sedangkan IPM Kalteng sebesar 71,05 dengan Rata-rata lama Sekolah 8,59 tahun, Harapan Lama Sekolah (HLS) sebesar 12,66 tahun, Angka Harapan Hidup (AHH) sebesar 69,74 tahun dan Pengeluaran Perkapita Pertahun adalah sebesar Rp. 11.154,00 ribu rupiah, sedangkan untuk IPM Kalsel sebesar 70,91 dimana Rata-rata lama Sekolah 8,29 tahun, Harapan Lama Sekolah (HLS) sebesar 12,52 tahun, Angka Harapan Hidup (AHH) sebesar 68,66 tahun dan Pengeluaran Perkapita Pertahun adalah sebesar Rp. 12.032,00 ribu rupiah.

Pengembangan pendidikan merupakan pada semua tingkatan merupakan salah satu unsur penting dalam proses pembangunan yang baik pada tingkat nasional dan wilayah. Selain itu juga dalam proses pembangunan harus lebih ditekankan pada pembangunan manusia yang berkualitas, seperti pengembangan pendidikan, peningkatan pelayanan kesehatan dan peningkatan penerapan teknologi tepat guna (Sjafrizal, 2018). Kalimantan Timur unggul dihampir semua indicator baik di rata-rata lama sekolah, harapan lama sekolah Umur Harapan Hidup (UHH) serta pengeluaran per kapita. Menurut Tyler dalam (Widiansyah, 2017) mengungkapkan bahwa pendidikan dapat meningkatkan produktivitas kerja seseorang, yang kemudian akan meningkatkan pendapatannya. Peningkatan pendapatan ini berpengaruh pula kepada pendapatan nasional negara yang bersangkutan, untuk kemudian akan meningkatkan pendapatan dan taraf hidup masyarakat berpendapatan rendah.

Konsep pendidikan yang berorientasi terhadap tenaga kerja merupakan investasi pendidikan, artinya bahwa pendidikan yang siap jual, siap guna dan siap mendiri atau yang disebut dengan pendidikan berbasis life skill (Putra, 2018). Pengeluaran per kapita merupakan salah satu capaian pembangunan manusia dalam mewujudkan kehidupan yang layak terkait dengan konsumsi riil per kapita (Dewi \& Sutrisna, 2014). Indeks pembangunan manusia memuat tiga dimensi penting dalam pembangunan yaitu terkait dengan aspek pemenuhan kebutuhan akan hidup panjang umur 
(longevity) dan hidup sehat (healthy life), untuk mendapatkan pengetahuan (the knowledge) dan mempunyai akses kepada sumberdaya yang bisa memenuhi standar hidup (Sayifullah \& Gandasari, 2016).

\section{Pertumbuhan Ekonomi dan IPM/HDI}

Begitu juga pertumbuhan ekonomi dan IPM/HDI peneliti mengklasifikasi menjadi empat kompenen, yakni 1) Daerah cepat maju dan cepat tumbuh atau provinsi yang memiliki IPM/HDI tinggi dan pertumbuhan ekonomi tinggi; (2) daerah maju tepi tertekan atau daerah dengan pertumbuhan ekonomi tinggi tetapi IPM/HDI rendah; (3) daerah berkembang cepat, yakni dengan IPM/HDI tinggi tetapi pertumbuhan ekonomi rendah; (4) daerah relative tertinggal, yakni IPM/HDI dan pertumbuhan ekonomi rendah. Adapun hasil dari penelitian ini dapat dilihat pada tabel 6 .

Tabel 6. Pertumbuhan Ekonomi dan IPM/HDI

\begin{tabular}{|c|c|c|}
\hline \multirow[b]{2}{*}{ IPM/HDI (r) } & \multicolumn{2}{|c|}{ Pertumbuhan ekonomi (y) } \\
\hline & $(y 1>y)$ & $(\mathrm{y} 1<\mathrm{y})$ \\
\hline$(\mathrm{r} 1>\mathrm{y})$ & $\begin{array}{l}\text { Pertumbuhan Ekonomi Tinggi \& } \\
\text { IPM/HDI tinggi: }\end{array}$ & $\begin{array}{l}\text { Pertumbuhan Ekonomi Rendah \& } \\
\text { IPM/HDI Tinggi: } \\
\text { Kalimantan Timur }\end{array}$ \\
\hline$(\mathrm{r} 1<\mathrm{y})$ & $\begin{array}{l}\text { Pertumbuhan Ekonomi Tinggi \& } \\
\text { IPM/HDI rendah: } \\
\text { Kalimantan Tengah } \\
\text { Kalimantan Utara }\end{array}$ & $\begin{array}{l}\text { Pertumbuhan Ekonomi Rendah \& } \\
\text { IPM/HDI rendah: } \\
\text { Kalimantan Barat } \\
\text { Kalimantan Selatan }\end{array}$ \\
\hline
\end{tabular}

Dari tabel di atas menjelaskan tentang pertumbuhan ekonomi dan IPM/HDI Provinsi Kalimantan, dimana pada tabel di atas menjelaskan bahwa hanya satu Provinsi yang berada pada klasifikasi daerah maju tepi tertekan atau daerah dengan pertumbuhan ekonomi tinggi tetapi IPM/HDI rendah yakni Kalimantan Tengah dan Kalimantan Utara, dimana rata-rata pada tahun 2015-2020 pertumbuhan ekonomi Kalimantan tengah sebesar 5,06\% dan IPM/HDI sebesar 69,97, sedangkan Kalimantan Utara pertumbuhan ekonominya sebesar 4,15\% dengan IPM/HDI sebesar 70,02. Sedangkan provinsi lainnya yakni provinsi Kalimantan Timur berada pada kuadran daerah berkembang cepat, yakni dengan IPM/HDI tinggi tetapi pertumbuhan ekonomi rendah dan provinsi Kalimantan Barat dan Selatan berada pada kuadran daerah relative tertinggal, yakni IPM/HDI dan pertumbuhan ekonomi rendah.

Pada pertumbuhan ekonomi dan HDI/IPM semua provinsi di Kalimantan tidak masuk kategori daerah maju dan cepat berkembang. Untuk daerah dengan pertumbuhan ekonomi rendah dan HDI rendah dalah Kalimantan Barat dan Kalimantan Selatan dimana pada tahun 2019 pertumbuhan ekonomi Kalbar sebesear 5,09\% pada tahun 2020 turun minus sebesar -1,82\% karena covid-19 dan dengan IPM/HDI sebesar 67,66 tahun 2020, sedangkan untuk Kalsel pada tahun 2019 sebesar 4,08\% pada tahun 2020 turun minus sebesar -1,81\% dengan IPM/HDI sebesar 70,91 pada tahun 2020. Untuk Kalimantan Tengah dan Kalimantan Utara berada kuadran pertumbuhan ekonomi tingi tetapi IPM/HDI rendah sedangkan untuk Kalimantan timur berada di kuadran daerah dengan pertumbuhan ekonomi rendah dan IPM/HDI tinggi.

Solow dalam (Asnidar, 2018) mengatakan bahwa pertumbuhan ekonomi selalu bersumber dari satu atau lebih dari tiga faktor kenaikan kuantitas dan kualitas manusia (tenaga kerja). Menurut (Ezkirianto \& Alexandi, 2018) pembangunan manusia yang tinggi memengaruhi proses pertumbuhan ekonomi, dan sebaliknya, pertumbuhan ekonomi yang tinggi memengaruhi kualitas pembangunan manusia. Namun tidak selalu pembangunan manusia yang tinggi disertai dengan pertumbuhan ekonomi yang tinggi pula, begitu pula sebaliknya. Begitu juga jika IMP tinggi tetapi tidak didukung oleh lapangan pekerjaan yang memadai maka akan memperbesar pengangguran (Prasetyoningrum, 2018). Upaya untuk mencapai pertumbuhan tinggi, pendapatan perkapita tinggi serta HDI tinggi untuk Kalimantan Barat memerlukan strategi yang mengarah pada konvergensi dalam ketiga bidang tersebut (Bariyah, 2015).

\section{Indeks Gini}

Indeks gini sering dipakai untuk mengukur ketimpangan dan sebagai salah satu indicator yang paling sering dipakai. Adapun indeks gini provinsi Kalimantan adalah sebagai berikut:

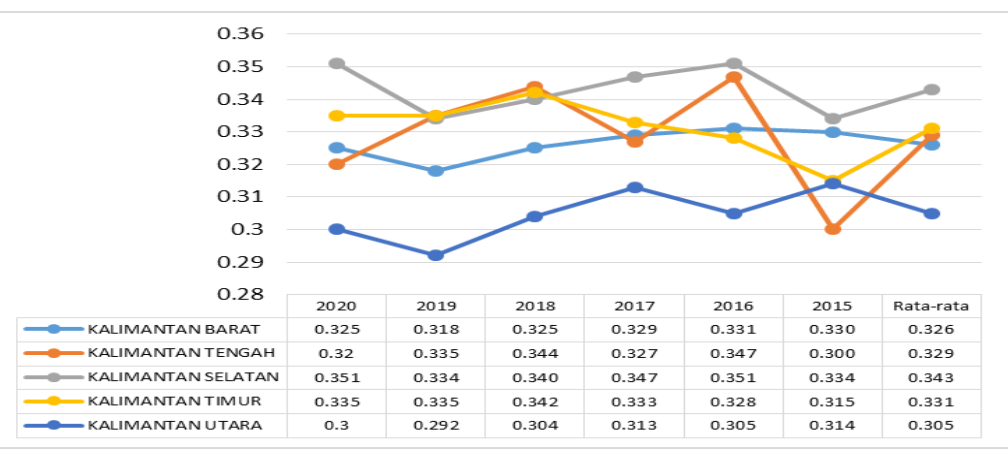

Gambar 3. Gini Rasio Pulau Kalimantan Tahun 2015-2020 
Data diatas adalah rata-rata ketimpangan dan Pertumbuhan ekonomi Pulau Kalimantan dan Indonesia tahun 20152020, dimana ketimpangan tertinggi adalah Kalimatan Selatan yakni sebesar 0,34 atau sebesar 34\%. Dari tahun $2015-$ 2020 Gini Rasio Kalimantan Selatan dominan terbesar yakni pada tahun 2015 sebesar 0,33, 2016 sebesar 0,35, 2017 sebesar 0,34 dan tahun 2020 sebesar 0,35.

Penyebab terjadinya ketimpangan di Kalimantan Selatan adalah semakin besar pertambagan tetapi tidak merata di Kabupaten/Kota, salain itu juga adanya perbedaan sumber daya alam atau kandungan yang ada di Kalimantan Selatan antar Kabupaten/Kota sehingga sebagian besar PDRBnya bertumpu pada sector pertambangan dan penggalian serta keberadaan sumber daya alam khususnya dalam sektor pertambangan mengalami tingkat produktivitas tinggi yang turut meningkatkan pendapatan perkapita daerahnya.

Selain itu juga menurut penelitian (Maulana et al., 2021), ketimpangan yang masih besar diakibatkan oleh beberapa kabupaten yang memiliki keunggulan Sumber Daya Alam (SDA) berupa melimpahnya komoditi batubara yang memiliki PDRB perkapita jauh diatas rata-rata Provinsi Kalimantan Selatan. Selain itu juga Kalimantan Timur berada pada posisi ketimpangan tertinggi nomor 2 dari pada Provinsi lainnya, rata-rata ketimpangan pada tahun 2015-2020 sebesar 0,331, dimana ketimpangan tertinggi adalah pada tahun 2018 yakni sebesar 0,442. Ketimpangan di Provinsi Kalimantan Timur disebabkan oleh ketidaklancaran proses perdagangan dan mobilitas faktor produksi antar daerah merupakan salah satu penyebab terjadinya ketimpangan wilayah (Suryani, 2012).

Ketimpangan daerah bisa terkait dengan anggaran belanja pembangunan yang terbatas atau tidak optimal, daya dukung infrastruktur yang kurang, kontribusi sektor ekonomi yang tidak seimbang atau terkait dengan pengaruh yang lainnya. Ketimpangan daerah yang dibiarkan secara terus menerus tersebut akan membawa pengaruh yang merugikan seperti terjadinya kecemburuan sosial antar daerah dan terganggunya kestabilan perekonomian.

\section{Indeks Williamson (IW)}

Untuk mengetahui ketimpangan pembangunan antar Kalimantan dapat dianalisi dengan menggunakan indeks ketimpangan regional (regional inequality) yang dinamakan indeks ketimpangan Williamson. Adapun hasil uji Indeks Williamson Pulau Kalimantan dapat dilihat pada gambar di bawah ini:

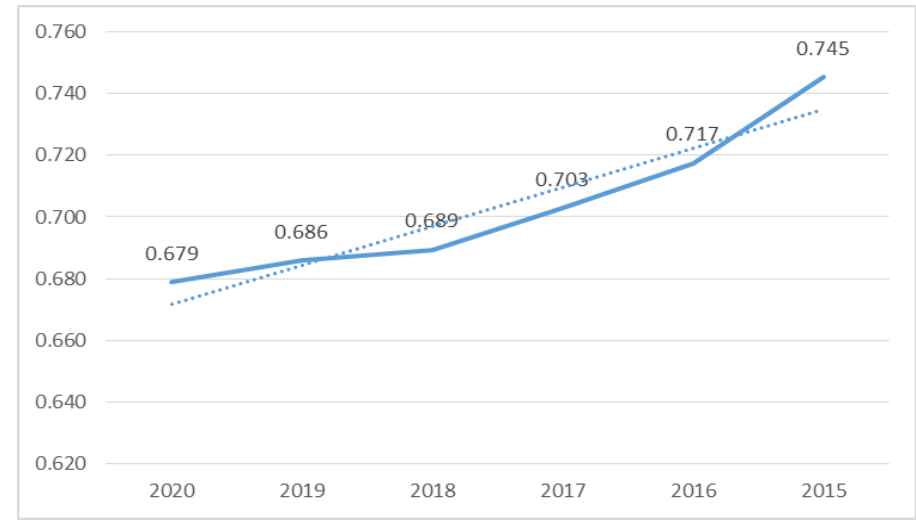

Gambar 4. Indeks Williamson Pulau Kalimantan Tahun 2015-2020

Hasil dari ketimpangan Indek Williamson di atas menunjukkan bahwa, pada tahun 2015-2020 ketimpangan Pulau Kalimantan mengalami perbaikan, hal ini dapat dilihat bahwa pada tahun 2015 sebesar 0,745 menjadi 0,679 pada tahun 2020 .

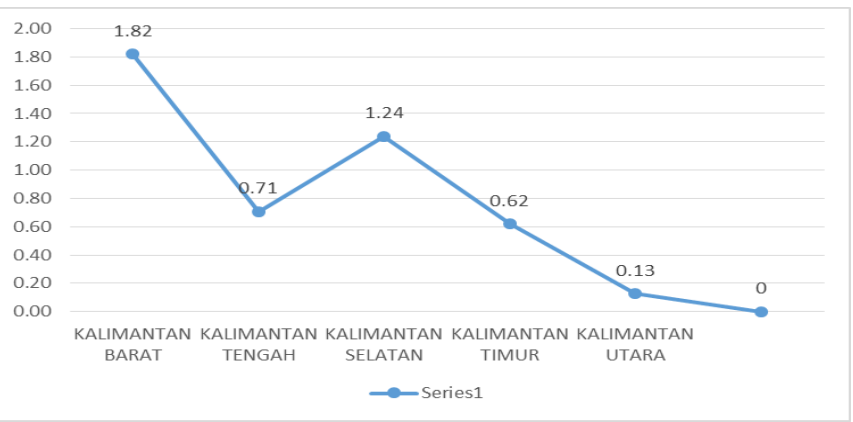

Gambar 5. Indeks Williamson Per Provinsi di Kalimantan Tahun 2015-2020

Sedangkan untuk ketimpangan antar provinsi di Kalimantan dapat dilihat pada gambar 4, dimana pada tahun 2015-2020 ketimpangan terbesar adalah Kalimantan Barat, yakni rata-rata ketimpangan Kalimantan Barat sebesar 1,82 dan disusul oleh Kalimantan Selatan yakni sebesar 1,24 dan ketimpangan terendah adalah Kalimantan Utara yakni 0,13. 


\section{Indek Entropi Theil (IT)}

Indeks Entropy Theil yang semakin besar menunjukkan bahwa ketimpangan yang terdapat pada suatu daerah/wilayah semakin besar atau ketimpangan di daerah tersebut tidak merata (Pamrihnan \& Cahyadin, 2016).

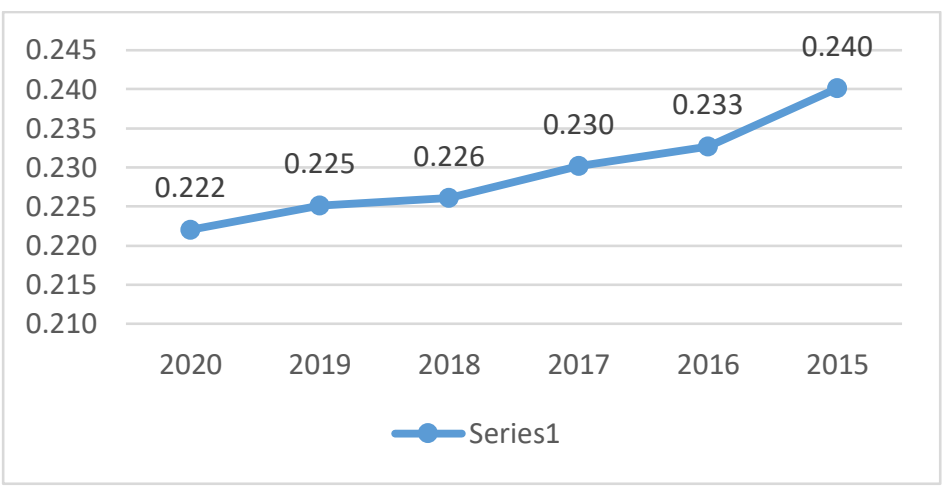

Gambar 6. Indeks Entropi Theil Pulau Kalimantan Tahun 2015-2020

Hasil dari ketimpangan Indek Entropi Theil di atas menunjukkan bahwa, pada tahun 2015-2020 ketimpangan Kalimantan mengalami perbaikan, hal ini dapat dilihat bahwa pada tahun 2015 sebesar 0,240 menjadi 0,222 pada tahun 2020. Menurut (Tambunan, 2016), factor yang menyebabkan ketimpangan pendapatan di Indonesia bahkan antar provinsi di Indonesia adalah karena ketimpangan pembangunan ekonomi antar provinsi, pada gilirannya akan disebabkan oleh infrastruktur (fisik maupun kualitas) kualitas SDM terutama pulau jawa dengan diluar pulau jawa. Sedangkan menurut Kuncoro dalam (Tambunan, 2016), menjelaskan bahwa penyebab terjadinya ketimpangan selama ini adalah karena factor efek backwash (negative) lebih besar dari pada efek penyebarannya (positif), karena selain factor ekonomi yang menyebabkan ketimpangan adalah factor kelembagaan, sejarah, social, politik dan bahkan kultural.

\section{KESIMPULAN}

Disparitas jumlah penduduk yang begitu besar, pengangguran yang makin bertambah menjadi salah satu penting pulau Kalimantan menjadi daerah dengan pertumbuhan ekonomi yang rendah, pendidikan yang rendah, terutama Kalimantan Barat, dari keliman Provinsi Kalimantan tersebut, tidak ada satupun Provinsi di Kalimantan yang memiliki keunggulan dari ketiga indicator (pertumbuhan ekonomi, PDRB perkapita dan HDI/IPM) tersebut. Sedangkan Kalimantan Utara merupakah daerah dengan keunggulan yang paling dominan dari indicator fundamental ekonomi selama tahun 20152020, yakni pertumbuhan ekonomi tertinggi, PDRB per kapita tertinggi, dan ketimpangan terendah. Pertumbuhan ekonomi yang tinggi harus didukung oleh program pengendalian pertumbuhan penduduk rendah pula, Kalimantan Barat dengan pertumbuhan ekonomi yang tinggi tetapi tidak didukung oleh program pengendalian laju pertumbuhan ekonomi oleh pemerintah daerah sehingga tidak bisa menjadi daerah maju dan cepat tumbuh. Selain itu juga walaupun pendapatan perkapita meningkat tetapi tidak didukung oleh pertumbuhan ekonomi hanya akan menjadi daerah dengan berkembang, dimana daerah berkembang ini sebagian besar penduduknya memiliki penghasilan disektor pertanian. Kalimantan Utara merupakan daerah dengan kategori cepat maju dan cepat tumbuh karena memiliki pertumbuhan ekonomi dan pendapatan perkapita yang tinggi, sedangkan Kalimantan Tengah merupakan daerah potensial karena memiliki pertumbuhan ekonomi tinggi tetapi pendapatan perkapita rendah, sedangkan untuk Kalimantan Barat, Kalimantan Selatan dan Kalimantan Timur merapakan daerah dengan kategori terbelakang artinya bahwa ketiga Kalimantan ini memiliki pertumbuhan ekonomi dan pendapatan perkapita rendah. Pendapatan perkapita juga penting dalam proses pembangunan daerah, tetapi harus didukung oleh Pembangunan manusia yang berkualitas. Hanya Kalimantan Timur yang memiliki kualifikasi daerah dengan maju dan cepat tumbuh serta Kalimantan Utara daerah dengan kategor Potensial karena pendapatan tinggi tetapi IPM/HDI rendah, sedangkan provinsi lainnya masuk dalam kategori daerah relative tertinggal yakni pertumbuhan ekonomi rendah dan IPM/HDI rendah. Untuk kategori pertumbuhan tinggi dan IPM/HDI tinggi provinsi Kalimantan tidak ada, sedangkan Kalimantan Tengah dan Kalimantan Utara masuk kategori daerah potensial yakni daerah maju tepi tertekan atau daerah dengan pertumbuhan ekonomi tinggi tetapi IPM/HDI rendah. Kalimantan Timur merupakan daerah berkembang atau daerah dengan pertumbuhan kecil tetapi IPM/HDI tinggi dan untuk daerah Kalimantan Barat dan Kalimantan Selatan merupakan daerah dengan ketegori terbelakang atau relative tertinggal dari daerah lainnya karena pertumbuhan ekonomi dan IPM/HDI rendah.

\section{REFERENCES}

Asnidar. (2018). Pengaruh Indeks Pembangunan Manusia (Ipm) Terhadap Pertumbuhan Ekonomi Di Kabupaten Wajo. JURNAL SAMUDRA EKONOMIKA, 2(1), 55.

Bariyah, N. (2015). Analisis Indikator Fundamental Ekonomi Daerah di Kalimatan Barat: Pertumbuhan Ekonomi, Pendapatan Perkapita dan HDI. Jurnal Ekonomi Bisnis Dan Kewirausahaan, 4(1), 72. https://doi.org/10.26418/jebik.v4i1.11462

Dewi, N. L. S., \& Sutrisna, I. K. (2014). Pengaruh Komponen Indeks Pembangunan Manusia Terhadap Pertumbuhan Ekonomi Provinsi 
Bali. E-Jurnal EP Unud, 3, 106-114.

Ezkirianto, R., \& Alexandi, M. F. (2018). Analisis Keterkaitan Antara Indeks Pembangunan Manusia Dan Pdrb Per Kapita Di Indonesia. Jurnal Ekonomi Dan Kebijakan Pembangunan, 2(1), 14-29. https://doi.org/10.29244/jekp.2.1.2013.14-29

Ismail, A. (2020). Pertumbuhan dan Ketimpangan Pembangunan Ekonomi Antar Daerah Di Provinsi Kalimantan Barat. Pertumbuhan Dan Ketimpangan Pembangunan Ekonomi Anatar Daerah Fi Provinsi Kalimantan Barat, 011, 143-159.

Iswanto, D. A., \& Maski, G. (2013). Pertumbuhan Ekonomi dan Pengangguran: Validitas Hukum Okun di Indonesia. Jurnal Ilmiah, 1-12. https://jimfeb.ub.ac.id/index.php/jimfeb/article/view/526

Kuncoro, M. (2015a). Mudah Memahami \& Menganalisis Indikator Ekonomi. Cetakan kedua. UPP STIM YKPN.

Kuncoro, M. (2015b). Mudah Memahami dan Menganalisis Indikator Ekonomi.

Lumbantoruan, E., \& Hidayat, P. (2014). Analisis Pertumbuhan Ekonomi Dan Indeks Pembangunan Manusia (Ipm) Provinsi-Provinsi Di Indonesia (Metode Kointegrasi). Jurnal Ekonomi Dan Keuangan, 2(2), 14780.

Maulana, A., Rosyidi, M. I., Koesfardani, C. F. P. P., Hidayah, S. A., \& Amory, I. D. G. R. A. (2021). Potensi Dampak Platform PeerTo-Peer Economy Airbnb Terhadap Usaha Penyediaan Akomodasi Di Provinsi Dki Jakarta. Jurnal Ekonomi Dan Pembangunan, 29(1), 59-80. https://doi.org/10.14203/jep.29.1.2021.59-80

Murohman, M., Hutagaol, M. P., \& Asmara, A. (2018). Peranan Sektor Ekonomi Dalam Pengentasan Kemiskinan Di Kalimantan Barat. Jurnal Ekonomi Dan Kebijakan Pembangunan, 3(1), 23-41. https://doi.org/10.29244/jekp.3.1.23-41

Pamrihnan, A., \& Cahyadin, M. (2016). ANALISIS KETIMPANGAN PENDAPATAN DAN IDENTIFIKASI SEKTOR BASIS ANTAR KECAMATAN DI KABUPATEN WONOGIRI TAHUN 2010-2014. JIEP, 16(November), 31-48.

Prasetyoningrum, A. K. (2018). Analisis Pengaruh Indeks Pembangunan Manusia (Ipm), Pertumbuhan Ekonomi, Dan Pengangguran Terhadap Kemiskinan Di Indonesia. Equilibrium: Jurnal Ekonomi Syariah, 6(2), 217. https://doi.org/10.21043/equilibrium.v6i2.3663

Putra, W. (2018). Perekonomian Indonesia Penerapan Beberapa Teori Ekonomi Pembangunan Di Indonesia.

Sayifullah, S., \& Gandasari, T. R. (2016). Pengaruh Indeks Pembangunan Manusia Dan Pengangguran Terhadap Kemiskinan Di Provinsi Banten. Jurnal Ekonomi-Qu, 6(2), 236-255. https://doi.org/10.35448/jequ.v6i2.4345

Sjafrizal. (2018). Ekonomi Regional Teori dan Aplikasi. Baduose Media.

Sukirno, S. (2016). Makro Ekonomi Modern. Perkembangan Pemikiran Dari Klasik Hingga Keynesian Baru. PT. RajaGrafindo Persada.

Suntari, M. V, \& Yunani, A. (2019). the Analysis of Economic Development Inequality and Inequality of Income Distribution in South Kalimantan Province (Case Study of Banjarmasin City and Tanah Bumbu Regency). Jurnal Ecoplan, 2(2), 67-76.

Suryani, S. (2012). ANALISIS PENGARUH FINANCING TO DEPOSIT RATIO (FDR) TERHADAP PROFITABILITAS PERBANKANSYARIAH DI INDONESIA (Rasio Keuangan pada BUS dan UUS Periode 2008-2010). Economica: Jurnal Ekonomi Islam, 2(2), 153-170. https://doi.org/10.21580/economica.2012.2.2.854

Tambunan, T. (2016). Pembangunan Ekonomi Inklusif. Sudah Sajauh Mana Indonesia?. LP3ES.

Waluyo, J. (2006). Hubungan Antara Tingkat Kesenjangan Pendapatan Dengan Pertumbuhan Ekonomi: Jurnal Ekonomi Pembangunan, 9(1), 1-20.

Widiansyah, A. (2017). Peran Ekonomi dalam Pendidikan dan Pendidikan dalam Pembangunan Ekonomi. Jurnal Cakrawala, XVII(2), $207-215$

Wihastuti, L. (2008). PERTUMBUHAN EKONOMI INDONESIA: Determinan dan Prospeknya. Jurnal Ekonomi \& Studi Pembangunan, 9(1), 30660 . 